\title{
A Numerical Comparison between Spiral Transverse RC and CFST Columns under Loads of Varying Eccentricities
}

\author{
Mojtaba Labibzadeh" ${ }^{*}$, Reza Jamalpour ${ }^{1}$, Deng H. Jing², Amin Khajehdezfuly ${ }^{1}$ \\ 1 Department of Civil Engineering, Faculty of Engineering, Shahid Chamran University of Ahvaz, \\ 61xxx Ahvaz, P. O. Box 6135713996 Iran \\ 2 School of Civil Engineering, Southeast University, 211189 Nanjing, 2 Southeast University Road, China \\ * Corresponding author, e-mail: labibzadeh_m@scu.ac.ir
}

Received: 09 April 2019, Accepted: 11 October 2019, Published online: 28 November 2019

\begin{abstract}
This paper is the first to present the results of a numerical comparison between the performances of two newly developed concrete columns namely: multi-tied spiral transverse reinforced (MTSTR) column and concrete-filled steel tube (CFST) column under eccentric compressive loads. The behavior of MTSTR columns under eccentric loads has not been studied until today and also this behavior is not compared to that of the CFST columns. The numerical models of these columns were constructed using the nonlinear finite element method and validated against the previously published experimental data in the literature. Concrete damage plasticity model and elastic-perfect plastic model were used to simulate the behavior of concrete core and steel of the columns, respectively. This provides the capability of modeling of the nonlinear large deformations of the columns. The obtained results show that the MTSTR columns can provide greater load carrying capacity, ductility, and energy absorption with slightly lower initial stiffness than the CFST columns under the same eccentricities. For instance, the load-carrying capacity of MTSTR column is 18 percent greater than that of the CFST column when the load eccentricity is $100 \mathrm{~mm}$. In case of $100 \mathrm{~mm}$ eccentricity, the ductility of the improved version of the MTSTR column proposed in this study is 30 percent greater than CFST one.
\end{abstract}

Keywords

multi-tied spiral transverse reinforced column, concrete-filled steel tube column, numerical analysis, eccentric load, load carrying capacity

\section{Introduction}

Columns have different performances in buildings depending on the loading conditions. Under vertical loads, columns behave as axial members and the axial stiffness and strength play a key role in the overall behavior of the building $[1,2]$. In this situation, ductility and energy dissipation capability of the columns are not considered as essential criteria in the design codes. However, under the lateral loads, column behaves as an axial-flexural-shear member and the flexural and shear stiffness play main roles in addition to its axial stiffness in the building performance [3-10]. Under this circumstance, ductility, and energy dissipation of the column cannot be ignored in the analysis and design procedures. This issue becomes more highlighted when the height of the building increases. In tall buildings, columns are subjected to significant axial, shear and bending moments due to the combination of gravity and wind or seismic loads [11-13].
The bearing capacity and deformability of the column are affected by configurations of the column cross-section [14-21]. The lack of load capacity, inadequate ductility, and low energy absorption are known as the most effective parametres on the column failure [22, 23]. Accordingly, several researchers attempted to improve the load capacity, ductility, and energy absorption of the column under different loads by means of confinement of the concrete core with different methods. An overview of recent literature shows that utilization of concrete-filled steel tubes (CFST) and transverse reinforcement (TR) are two effective ways to improve the confinement of concrete core and increase of the load carrying capacity, ductility, and energy absorption.

The results of the previous experimental studies show that the ductility and strength of CFST columns are more than those of traditional columns [24-30]. Lam and Williams [31] examined the performance of CFST columns 
experimentally subjected to axial compressive loads and found that the increase of the compressive strength of concrete leads to an increase in the bearing capacity of the column. Sakino et al. [32] presented stress-strain relationships for concrete of the CFST columns under the axial loads through an experimental investigation. The eccentric compressive loads are also induced in the columns during the earthquake [33]. In an experimental research, Xiong et al. [34] evaluated the bearing capacity of the CFST columns under eccentric loads. They found that as the yield stress of the steel tube increases, the bearing capacity of the CFST columns increases. In Lee et al.'s investigation [35], eccentric load was applied to the short CFST columns. In addition to experimental works, many researchers have studied the behavior of CFST columns using analytical and numerical methods. Wang et al. [36] simulated the CFST columns wrapped with the CFRP fibers under eccentric load and concluded that the CFST columns with CFRP fibers have greater bearing capacity and ductility compared to those of regular CFST column. In a research carried out by Li et al. [37], eccentric loads were applied to the CFST short columns in laboratory. They also simulated the behavior of these columns using finite element method. They found that the most significant effect of the confinement concrete is observed in the corner of the pillow. They also derived the change of the force-moment interaction diagrams of this type of columns against different parameters and presented some relationships for calculation of the maximum bearing capacity of CFST column. Liu et al. [38] studied the CFST columns with different cross-sections under axial load using a laboratory and a finite element method. Their investigation presented that CFST columns with a T-shaped cross-section are more efficient than CFST columns with an L-section.

Tran and Li [39-42] used different configurations of transverse reinforcement in concrete columns and examined the performance of the constructed columns under cyclic loads. They proposed a formula to predict the initial stiffness of the RC columns. The spiral reinforcement was used for the first in the bridge columns. The load capacity of bridge's column were increased by using spiral reinforcement. In recent years, the use of spiral reinforcement in the columns of the residential buildings has been of great interest to the researchers. Jing et al. [43] applied compressive load to the column with spiral reinforcement in the laboratory. They proposed a new configuration of spiral reinforcement columns called MTSTR (multi-tiedspiral transverse reinforcement). In another experimental research carried out by Li et al. [44], the bearing capacity of the column with MTSTR under axial compression has been investigated. They proposed a stress-strain model for confined concrete used in the MTSTR column [45].

In the above-mentioned previous studies, the ductility and energy absorption of the MTSTR columns were investigated only under the axial loads. Moreover, these characteristics of the MTSTR and CFST columns have not been compared with each other until today. This research is an attempt to overcome to these shortcomings.

\section{Numerical simulation}

MTSTR and CFST columns were modeled numerically using the ABAQUS/Standard software. Several steps were needed for develop each column FE model. These steps include the geometry description, definition of the material behavior, determination of the element types and sizes, definition of the loading scenarios, determination of the boundary conditions and interactions, and finally the analysis type. These steps are briefly described for each column type in Subsections 2.1 and 2.2.

\subsection{Simulation of MTSTR column}

\subsubsection{Geometry description}

Rectangular concrete short column, spiral transverse reinforcement, longitudinal reinforcement, rigid cap and rectangular stirrup are the essential ingredients of the MTSTR column. The rectangular hoops were generated as wire (truss elements). In addition, rectangular concrete column, rigid cap, longitudinal reinforcement, and spiral reinforcement were simulated as solid. All components were assembled to develop the MTSTR short column (See Fig. 1(a)). The longitudinal, spiral transverse and rectangular stirrup reinforcements were placed into the concrete short column. Fig. 1(b) displays a view of the arrangement of all the reinforcements in the column. A rigid cap is placed on the top of the column to apply a desired eccentric axial compression load on the column. Moreover, another rigid cap was located on the bottom of the column to apply the boundary condition of the column. As illustrated in Fig. 1(b), the concrete was confined by the spiral reinforcement.

\subsubsection{Material properties}

Two types of material, namely concrete and steel are used to simulate MTSTR column. The longitudinal, spiral transverse and rectangular stirrup reinforcements and rigid caps were considered as steel and short column was considered as concrete. Concrete damage plasticity model 


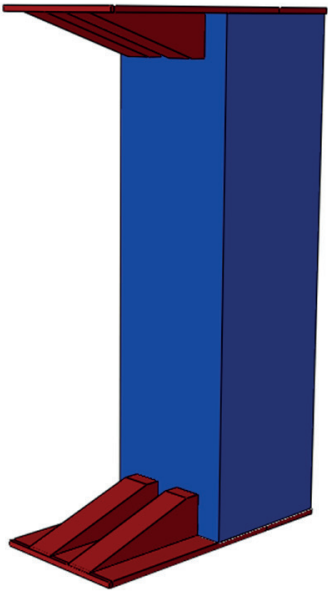

(a)

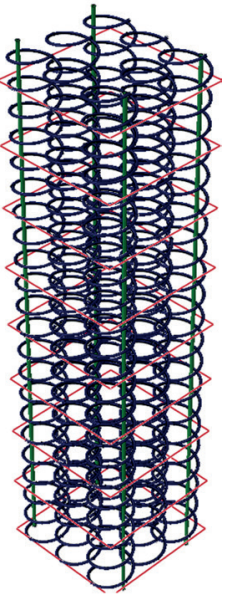

(b)
Fig. 1 Details of MTSTR column a) a view of MTSTR column b) arrangement of reinforcement

was used to define the concrete behavior. This material model has been used to take into account the concrete plastics and damages. Several input parameters such as uniaxial compressive and uniaxial tensile stress-strain relationships and plasticity parameters have to be defined for the CDP model. Uniaxial compressive stress-strain relationship of concrete is defined using in Eqs. (1)-(7) [46-48].

$\frac{\sigma_{c}}{\sigma_{o}}=\left\{\begin{array}{cc}2 x-x^{2} & x \leq 1 \\ \frac{x}{\beta_{0}(x-1)^{\eta_{0}}+x} & x>1\end{array}\right.$

$x=\frac{\varepsilon_{c}}{\varepsilon_{0}}$

$\sigma_{0}=f_{c}$

$\varepsilon_{0}=\left[\left(1300+12.5 \times f_{c}\right)+800 \times \theta^{0.2}\right] \times 10^{6}$

$\eta_{0}=1.6+\frac{1.5}{x}$

$\beta_{0}=f_{c}^{0.1} /(1.2 \sqrt{1+\theta})$

$\theta=A_{s} f_{y} / A_{c} f_{c}$

In Eq. (1), two coefficients $\beta_{0}$ and $\eta_{0}$ are used to calculate stress-strain relations of concrete in compression state. $\beta_{0}$ and $\eta_{0}$ are calculated using Eqs. (5) and (6). Also, in formula (Eq. (1)), $\sigma_{c}$, is the compressive stress of concrete and $\sigma_{0}$ denotes the maximum compressive stress of concrete. In Eq. (2), $\varepsilon_{0}$ is the maximum compressive strain of concrete and $\varepsilon_{c}$ is the compressive strain of concrete. In the Eq. (7), $A_{S}$ defines the cross- sectional area of steel, $f_{y}$ is the yield stress of steel and $A_{C}$ stands for the concrete cross-sectional area. Uniaxial tensile behavior of concrete was defined using in Eqs. (8)-(11) [46-48].

$\frac{\sigma_{t}}{\sigma_{p}}=\left\{\begin{array}{cc}1.2 x-0.2 x^{6} & x \leq 1 \\ \frac{x}{0.31 \sigma_{0}^{2}(x-1)^{1.7}+x} & x>1\end{array}\right.$

$x=\frac{\varepsilon_{t}}{\varepsilon_{p}}$

$\sigma_{p}=0.26\left(1.2 \times f_{c}\right)^{2 / 3}$

$\varepsilon_{p}=43.1 \sigma_{p} \times 10^{6}$

In Eq. (9), $\sigma_{p}$ is the maximum tensile stress of concrete and $\sigma_{t}$ is the tensile stress of concrete. In Eq. (9), $\varepsilon_{p}$ is the maximum tensile strain of concrete and $\varepsilon_{t}$ denotes the concrete tensile strain [46-48]. The optimum values of the plasticity input parameters of the CDP model including the dilation angle $(\psi)$, eccentricity $(\epsilon)$, the ratio of the biaxial compressive strength to the uniaxial compressive strength of the concrete $\left(f_{b 0} / f_{c 0}\right)$, the ratio of the tensile meridian to the compressive meridian in the deviatoric plane of the yield surface $\left(K_{c}\right)$, and viscosity $(\mu)$ were introduced in Table 1 [49-61].

An elastic-plastic material model was considered to simulate the behavior of steel $[62,63]$. Some parameters such as modulus of elasticity, Poisson's ratio, yield, and ultimate stress of steel are utilized to define the elastic-plastic behavior of steel. This material model was assigned to all reinforcements and rigid caps. The modulus of elasticity of rigid caps was considered eight times larger than that of reinforcement, to increase the rigidity of the rigid caps. The material characteristics of concrete and steels used in this study is outlined in Table 2.

\subsubsection{Type and size of elements}

Three dimensional eight-node brick elements (C3D8R) were used to simulate the concrete, spirals, longitudinal bars, and rigid caps. The rectangular hoops were modeled using two-node truss elements, T3D2. According to the results obtained from several sensitivity analyses, the size of the elements of concrete and steel parts were chosen as $50 \mathrm{~mm}$ and $25 \mathrm{~mm}$ respectively.

Table 1 Plasticity Parameters of Concrete

\begin{tabular}{lcccc}
\hline Dilation Angle & Eccentricity & $f_{b 0} / f_{c 0}$ & $K$ & Viscosity Parameter \\
\hline $40^{\circ}$ & 0.1 & 1.16 & 0.66 & 0.0001 \\
\hline
\end{tabular}


Table 2 Material properties of concrete and steels

\begin{tabular}{lccc}
\hline Material & $\begin{array}{c}\text { Yield Stress } \\
(\mathrm{MPa})\end{array}$ & $\begin{array}{c}\text { Ultimate } \\
\text { Stress }(\mathrm{MPa})\end{array}$ & $\begin{array}{c}\text { Elastic Modules } \\
(\mathrm{MPa})\end{array}$ \\
\hline Concrete & - & 41 & $3 \times 104$ \\
$\begin{array}{l}\text { Steel of spirals } \\
\text { Steel of }\end{array}$ & 1196.7 & 1349.7 & $2.1 \times 105$ \\
$\begin{array}{l}\text { longitudinal bars } \\
\text { Steel of stirrups }\end{array}$ & 344.7 & 503.6 & $2.1 \times 105$ \\
\hline
\end{tabular}

\subsubsection{Loading, boundary conditions and interactions}

Rectangular stirrup reinforcement, longitudinal reinforcement and spiral reinforcement were embedded in the concrete. In other words, the displacements of each node of all reinforcement were regarded the same as those of the concrete node. The rigid caps were tied to the top and bottom surfaces of the column. Hence, the displacements of the rigid cap at the top of the column were considered the same as those of the top surface of the column. Furthermore, the displacements of the rigid cap at the bottom of the column were considered the same as those of the bottom surface of the column. The compressive loads were applied as the controlled displacements across the two opposite lines on the top and bottom rigid caps to simulate the eccentricity (green lines in Fig. 2). The loading and boundary conditions of the MTSTR column are shown in Fig. 2. As shown in Fig. 2, the displacement of the bottom rigid cap is restrained in all transitional directions. The displacement of the top rigid cap in 1 and 3 directions is restricted $(\mathrm{U} 1=\mathrm{U} 3=0$ ) (see Fig. 2). Rotations of the bottom and top rigid caps about 1 and 2 axes were restrained $(\mathrm{UR} 3=\mathrm{UR} 2=0)$.

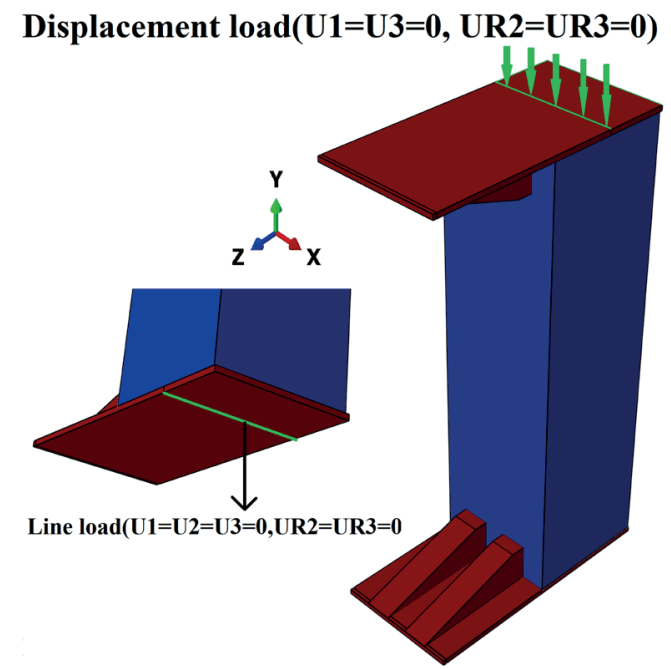

Fig. 2 Loading and boundary conditions of MTSTR column

\subsubsection{Analysis}

Static analysis was used to obtain the MTSTR column response under axial compressive load with eccentricity. The time period and the maximum number of increment for analysis were considered as 1 and 10000, respectively.

The time period and the maximum number of increment for analysis were considered as 1 and 10000, respectively. The load-displacement diagram of the column was obtained based on the calculated reaction force of bottom rigid cap and applied displacement of the top rigid cap.

\subsection{Simulation of CFST column}

The CFST column includes a steel tube, rectangular concrete column and, rigid caps. The steel tube was generated as shell elements and other components of the CFST column were generated as solid elements. The concrete column was placed into the steel tube and rigid caps were placed at the top and bottom of the column. Fig. 3 shows a schematic view of the CFST column. The material behavior of the steel tube was considered as the steel behavior described in Subsection 2.1.2. The material behaviors of the other components of the CFST column were considered the same as those of MTSTR column.

The steel tube was simulated using S4R elements. S4R element is a four- nodded shell element and in each node, six degrees of freedom (transitional and rotational) were defined. Other components of the CFST column have meshed the same as MTSTR column. The size of the element was considered $50 \mathrm{~mm}$. The steel tube was tied to the concrete column. The loading, interaction and boundary conditions of other components of the CFST column were considered the same as the MTSTR column. Moreover, the analysis procedure of the CFST column resembles that of the MTSTR column.

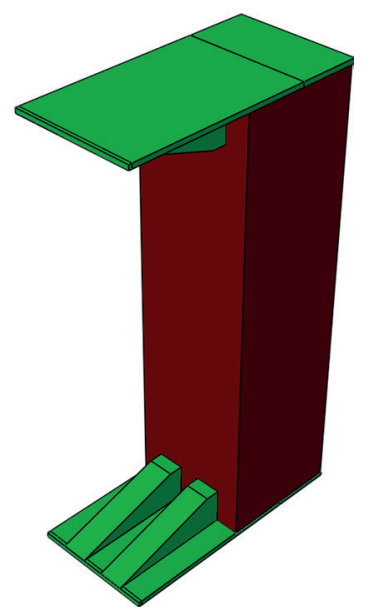

Fig. 3 View of CFST column 


\section{Verification of numerical models}

The results obtained from the models developed in Subsection 2.2 (MTSTR column and CFST column) were compared to those of the literature to investigate the validity of the results obtained from the models. The details are described in Subsections 3.1 and 3.2.

\subsection{MTSTR column}

The behavior of MTSTR column under axial compressive load was investigated by $\mathrm{Li}$ et al. [44, 45]. The columns with square shape cross-section were tested in their research. The width (B) and height (L) of the columns were considered as $250 \mathrm{~mm}$ and $900 \mathrm{~mm}$, respectively. The rectangular stirrup reinforcement and transverse spiral reinforcement (with a diameter of $4 \mathrm{~mm}$ ) were considered in their columns. A longitudinal reinforcement with a diameter of $6 \mathrm{~mm}$ was placed at each corner of the columns. The diameter and space of the stirrup reinforcement were considered as $6 \mathrm{~mm}$ and $100 \mathrm{~mm}$, respectively. Four specimens of MTSTR column with different properties were tested. The details of the MTSTR column specimens such as cross-section type, number of spiral reinforcement, the vertical spacing of the spirals and diameter of the spirals are presented in Table 3. The arrangement of the reinforcement and column type are displayed in Fig. 4. In the research attempts carried out by Jing et al. [43] and Li et al. [44, 45], the diagrams of the axial compressive load-axial strain of the columns were obtained when the specimens were subjected to the axial compressive load (using a jack).

All specimens listed in Table 3 are simulated in this study. The strength of the concrete and reinforcements were considered based on the data presented in Table 2 [43-45]. Moreover, the plasticity parameters of the concrete were considered according to Table 1. In Fig. 5, the results obtained from the numerical models are compared with those of the Jing et al. [43] and Li et al. [44, 45].

As illustrated in Fig. 5, a plausible agreement is seen between results obtained from the numerical model and experimental ones and. Minor differences between tests and models are due to limitation, simplification, and assumption

Table 3 Details of MTSTR column specimen

\begin{tabular}{lcccc}
\hline Specimen & $\begin{array}{c}\text { Type of } \\
\text { section }\end{array}$ & $\begin{array}{c}\text { Number } \\
\text { of spirals }\end{array}$ & $\begin{array}{c}\text { Vertical } \\
\text { Spacing of } \\
\text { Spirals, S (mm) }\end{array}$ & $\begin{array}{c}\text { The diameter } \\
\text { of the spiral, } \\
\text { D (mm) }\end{array}$ \\
\hline STR1 & C & 4 & 40 & 70 \\
STR2 & B & 4 & 40 & 100 \\
STR3 & A & 8 & 40 & 70 \\
STR4 & A & 8 & 60 & 70 \\
\hline
\end{tabular}
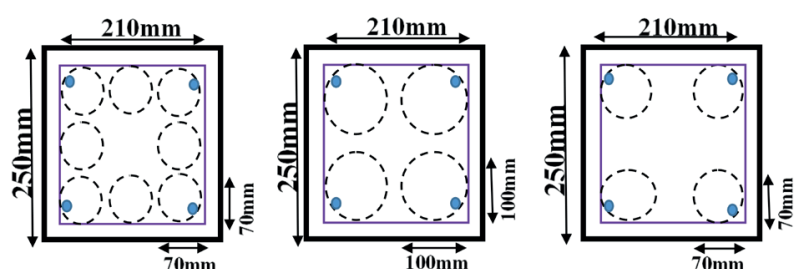

(a)

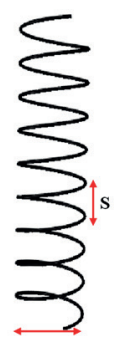

(b)

Fig. 4 Details of MTSTR column (a) cross section type (b) spiral properties

Table 4 Ultimate bearing capacity of MTSTR column obtained from model and test

\begin{tabular}{lccc}
\hline Specimen & $\mathrm{Pu}($ Exp $) \mathrm{kN}$ & $\mathrm{Pu}(\mathrm{FEM}) \mathrm{kN}$ & $\mathrm{Pu}(\mathrm{Exp}) / \mathrm{Pu}(\mathrm{FEM})$ \\
\hline STR1 & 2900 & 2960 & 0.97 \\
STR2 & 3100 & 3150 & 0.98 \\
STR3 & 3350 & 3430 & 0.97 \\
STR4 & 2900 & 3165 & 0.91 \\
\hline
\end{tabular}

considered in the numerical models. Moreover, the ultimate bearing capacity of the column obtained from the numerical model and test are compared in Table 4. As shown in Table 4, the maximum difference between the numerical model (FEM) and test are approximately less than 9 percent.

\subsection{Model of CFST column}

Li et al. [37] performed an experimental investigation of the behavior of the CFST column under axial load with eccentricity. The CFST column specimens (with square shape cross-section) had width and height of $150 \mathrm{~mm}$ and $450 \mathrm{~mm}$, respectively. The details of CFST column specimens are presented in Table 5 [37]. In the research carried out by Li et al. [37], the CFST column specimens were subjected to the eccentric compressive axial load. The numerical models of CFST column specimens presented in Table 5 were simulated in the current study. The concrete plasticity parameters were considered similar to the data presented in Table 3. The diagram of the axial load-axial displacement of the column was obtained from the developed models. A comparison has been made between the results obtained from the models and those of Li et al. [37] (see Fig. 6). As illustrated in Fig. 6, a slight difference is 


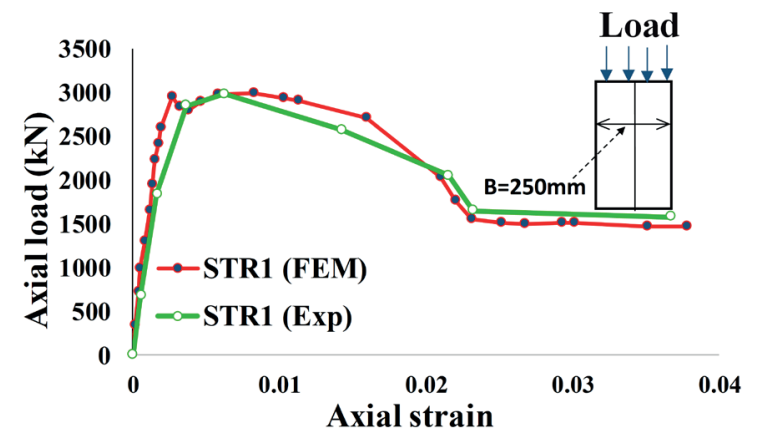

(a)

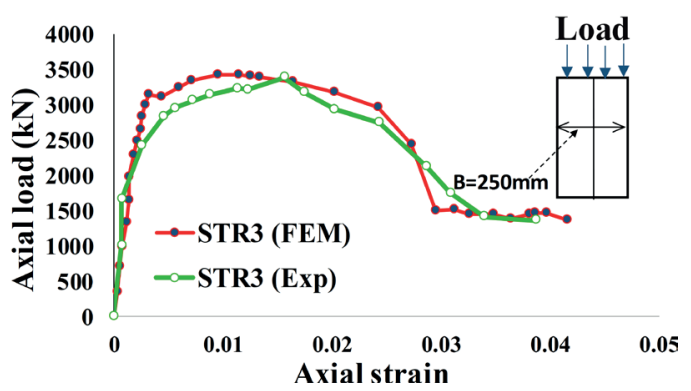

(c)

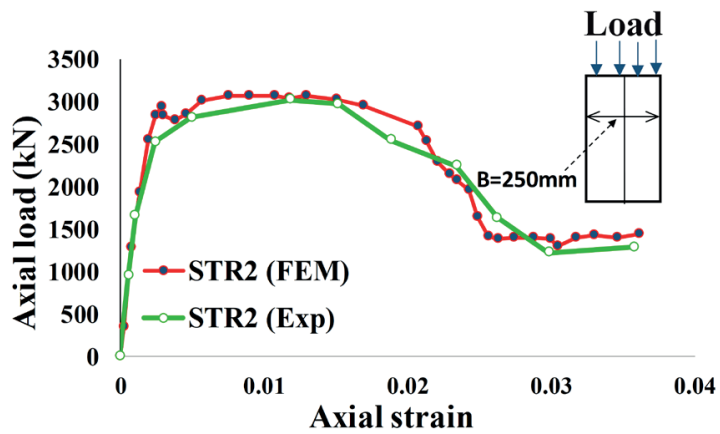

(b)

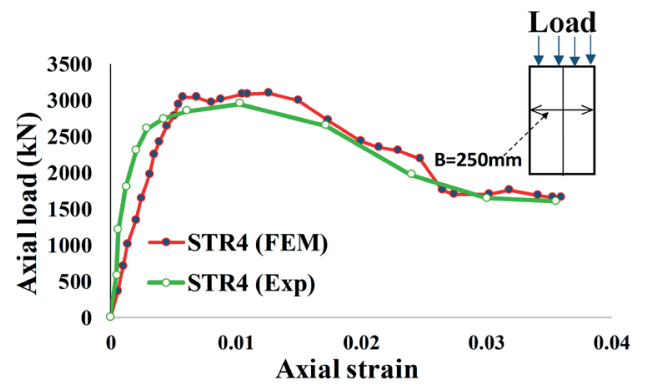

(d)

Fig. 5 Comparison between results of MTSTR numerical model and those of literature

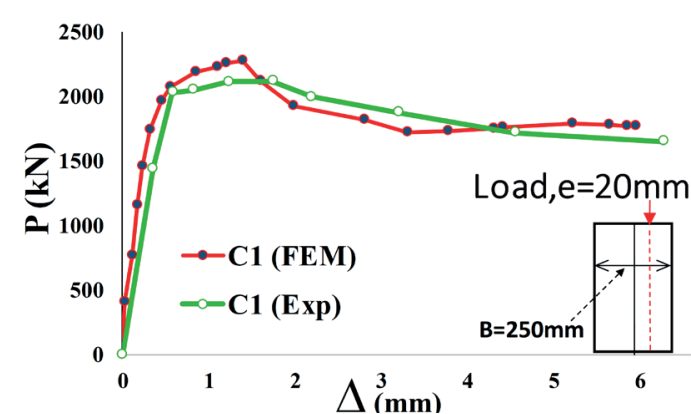

(a)

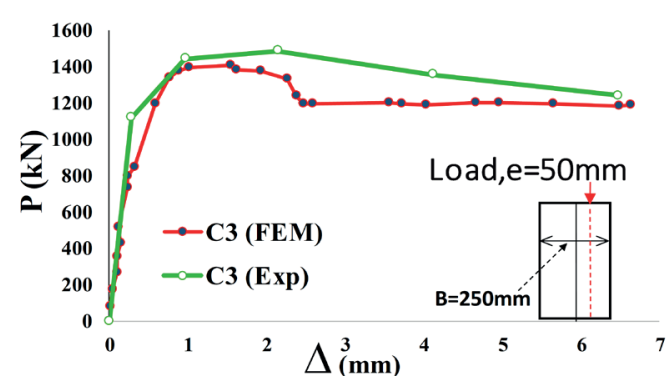

(c)

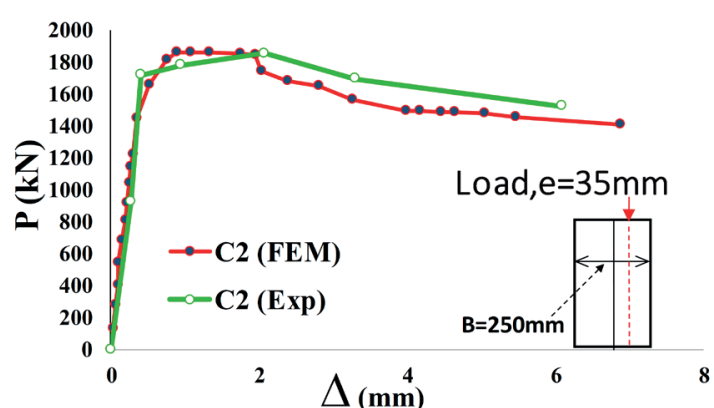

(b)

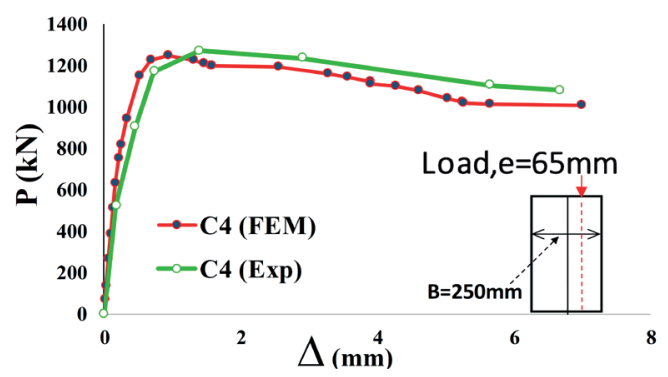

(d)

Fig. 6 Comparison between results of CFST numerical model and those of literature

Table 5 Properties of CFST column specimens

\begin{tabular}{lcccccc}
\hline Specimen & $B(\mathrm{~mm})$ & $\mathrm{t}(\mathrm{mm})$ & $\mathrm{L}(\mathrm{mm})$ & $\mathrm{e}(\mathrm{mm})$ & $f_{y}(\mathrm{MPa})$ & $f_{u}(\mathrm{MPa})$ \\
\hline $\mathrm{C} 1$ & 150 & 4 & 450 & 20 & 434.56 & 546.2 \\
$\mathrm{C} 2$ & 150 & 4 & 450 & 35 & 534.56 & 58 \\
$\mathrm{C} 3$ & 150 & 4 & 50 & 65 & 434.56 & 54.2 \\
$\mathrm{C} 4$ & 150 & 4 & 450 & 834.56 & 546.2 \\
\hline
\end{tabular}


Table 6 Peak- load of CFST column obtained from model and test

\begin{tabular}{lccc}
\hline Specimen & $\mathrm{Pu}(\mathrm{Exp}) \mathrm{kN}[37]$ & $\mathrm{Pu}(\mathrm{FEM}) \mathrm{KN}$ & $\mathrm{Pu}(\mathrm{Exp}) / \mathrm{Pu}(\mathrm{FEM})$ \\
\hline $\mathrm{C} 1$ & 2114.4 & 2248.5 & 0.94 \\
$\mathrm{C} 2$ & 1885.9 & 1864.88 & 1.011 \\
$\mathrm{C} 3$ & 1561.4 & 1448.5 & 1.077 \\
$\mathrm{C} 4$ & 1265 & 1246.89 & 1.014 \\
\hline
\end{tabular}

observed between the results obtained from the FEM and the experimental one. It means that the numerical models of the CFST column developed in this study are capable to predict the behavior of these columns under eccentric axial loads. In Table 6, the peak-loads of the CFST column specimens obtained from the models are compared with those of the literature. As shown in Table 6, the maximum difference between the peak loads derived from the numerical models and tests is about 7 percent.

\section{Comparison of the performance of the MTSTR and CFST under axial eccentric load}

In order to compare the performance of the MTSTR and CFST short columns, three models of MTSTR (STR3, MSTR, and ASTR) and one model of CFST column, were developed and analyzed under axial and eccentric compressive loads. The specifications of the models are summarized in Table 7 and Fig. 7.

Table 7 Details of the specimens simulated in ABAQUS

\begin{tabular}{|c|c|c|c|c|c|c|c|}
\hline $\begin{array}{l}\text { 巳ี } \\
\text { : } \\
\stackrel{0}{0} \\
\text { के }\end{array}$ & 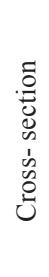 & 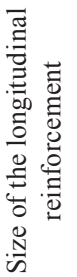 & 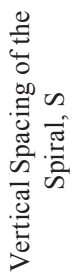 & 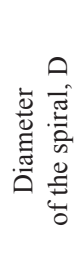 & 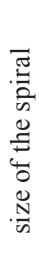 & 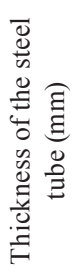 & 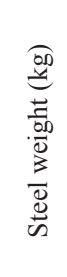 \\
\hline STR3 & $\mathrm{F} 1$ & 4 & 40 & 70 & 4 & - & 6.2 \\
\hline MSTR & $\mathrm{F} 1$ & 6 & 40 & 70 & 6 & - & 10.96 \\
\hline ASTR & $\mathrm{F} 1$ & 20 & 40 & 70 & 6 & - & 18.56 \\
\hline CFST & F2 & - & - & - & - & 3 & 21.6 \\
\hline
\end{tabular}
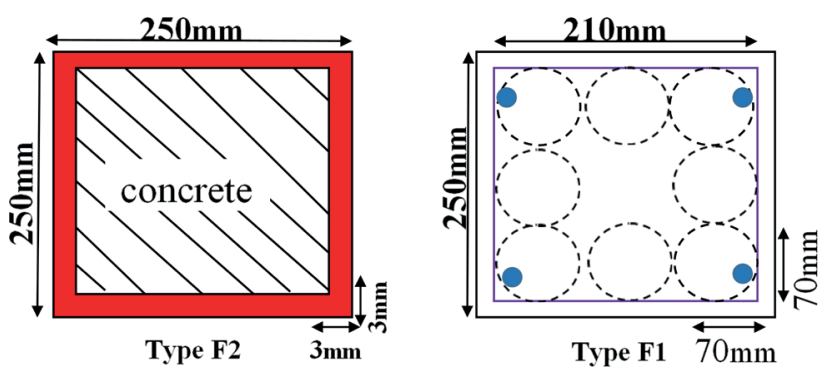

Fig. 7 Cross-sections of the columns constructed in ABAQUS
The bearing capacity of strongest of MTSTR column (STR3) under pure compressive axial load was the same as that of CFST column (about $3430 \mathrm{kN}$ ). In the CFST column, the yield and ultimate stresses of the steel were considered as $344 \mathrm{MPa}$ and $503 \mathrm{MPa}$ respectively. In the MTSTR columns, the yield and ultimate stress of the steel were considered the same as outlined in Table 2.

In Table 7, the dimensions of each section are $250 \times$ $250 \mathrm{~mm}$ and the height of the all columns is $900 \mathrm{~mm}$. The weight of the steel consumed in each configuration was calculated and indicated in Table 7. The distance between the rectangular hoops is $100 \mathrm{~mm}$ and the size of the rectangular hoops is $6 \mathrm{~mm}$. In all MTSTR columns, there are four longitudinal reinforcements, as shown in the cross-sections of the columns (see Fig. 7).

The ductility $\left(\mu_{0.85}\right)$ was defined based on Eq. (12) and Fig. 8. In Eq. (12), $\Delta_{0.85}$ is the axial displacement of the column at an axial load consistent to $85 \%$ of the maximum axial load on the descending branch of the axial load-displacement curve (see Fig. 8) and $\Delta_{y}$ stands for the axial displacement at the limit of elastic behavior (see Fig. 8) [64]. In Fig. 9, the MTSTR columns having eight spiral reinforcements, and were subjected to the axial and eccentric loads. The force-displacement diagrams of MTSTR columns are compared with the CFST column in Fig. 8.

$\mu_{0.85}=\frac{\Delta_{0.85}}{\Delta_{y}}$

Moreover, the maximum bearing capacity $(\mathrm{Pu})$ and the ductility $\left(\mu_{0.85}\right)$ of the columns under axial and eccentric loads are presented in Table 8. According to Fig. 9 and Table 8, although the bearing capacity of the STR3 column is close to that of CFST column, the ductility of STR3 column is two times greater than the CFST column one (7.29 for STR3 and 3.307 for CFST).However, under the eccentric load, strength of STR3 column was less than

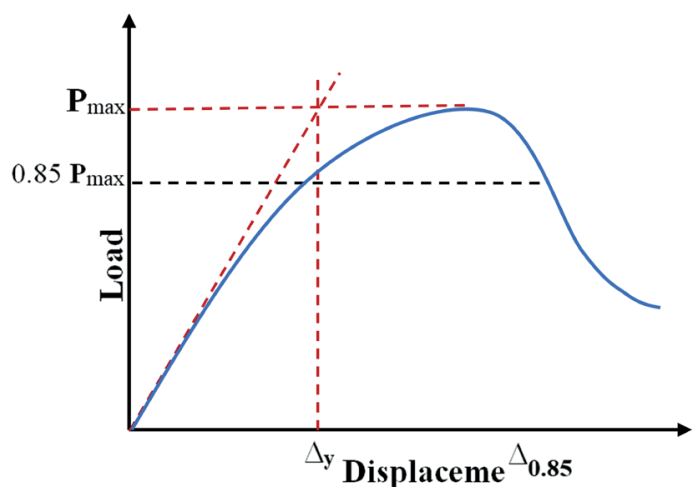

Fig. 8 Determination procedures of displacement ductility index 
Table 8 Key test results in ABAQUS

\begin{tabular}{lcccccccc}
\hline $\begin{array}{l}\text { Column } \\
\text { type }\end{array}$ & $\begin{array}{c}\mathrm{Pu}(\mathrm{kN}) \\
\mathrm{e}=0 \mathrm{~mm}\end{array}$ & $\begin{array}{c}\mathrm{Pu}(\mathrm{kN}) \\
\mathrm{e}=50 \mathrm{~mm}\end{array}$ & $\begin{array}{c}\mathrm{Pu}(\mathrm{kN}) \\
\mathrm{e}=75 \mathrm{~mm}\end{array}$ & $\begin{array}{c}\mathrm{Pu}(\mathrm{kN}) \\
\mathrm{e}=100 \mathrm{~mm}\end{array}$ & $\begin{array}{c}\mu_{0.85} \\
\mathrm{e}=0 \mathrm{~mm}\end{array}$ & $\begin{array}{c}\mu_{0.85} \\
\mathrm{e}=50 \mathrm{~mm}\end{array}$ & $\begin{array}{c}\mu_{0.85} \\
\mathrm{e}=70 \mathrm{~mm}\end{array}$ & $\begin{array}{c}\mu_{0.85} \\
\mathrm{e}=100 \mathrm{~mm}\end{array}$ \\
\hline STR3 & 3422 & 2194 & 1635 & 1258 & 7.29 & 7.35 & 8.65 & 6.78 \\
MSTR & 4335 & 2980 & 2342 & 1845 & 7.88 & 7.48 & 9.02 & 7 \\
ASTR & 4855 & 3614 & 2872 & 2400 & 8.125 & 10 & 10.666 & 8.18 \\
CFST & 3475 & 2256 & 1858 & 1559 & 3.307 & 6.25 & 6.667 & 6.28 \\
\hline
\end{tabular}

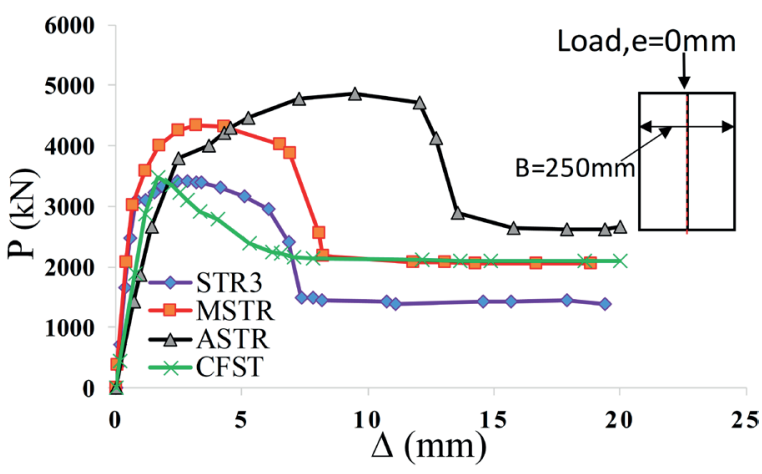

(a)

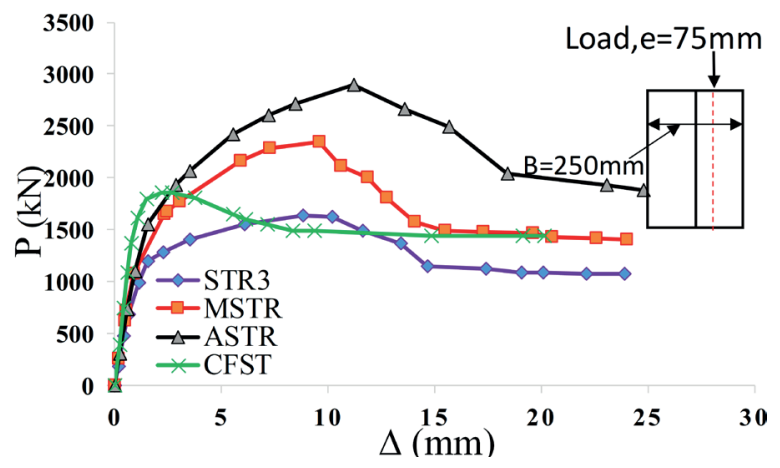

(c)

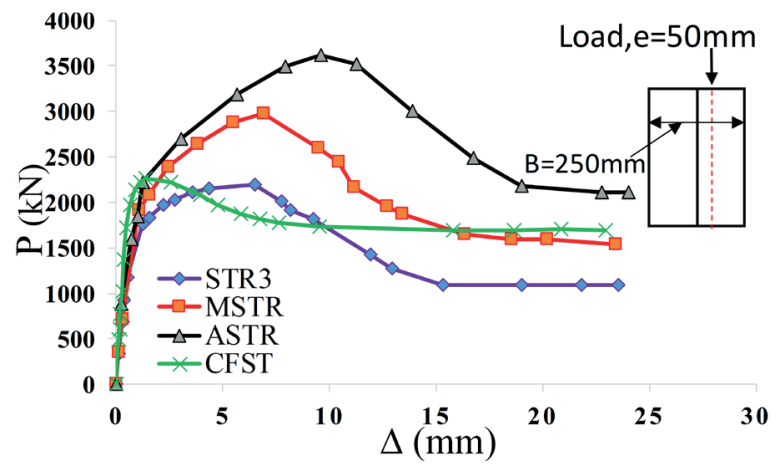

(b)

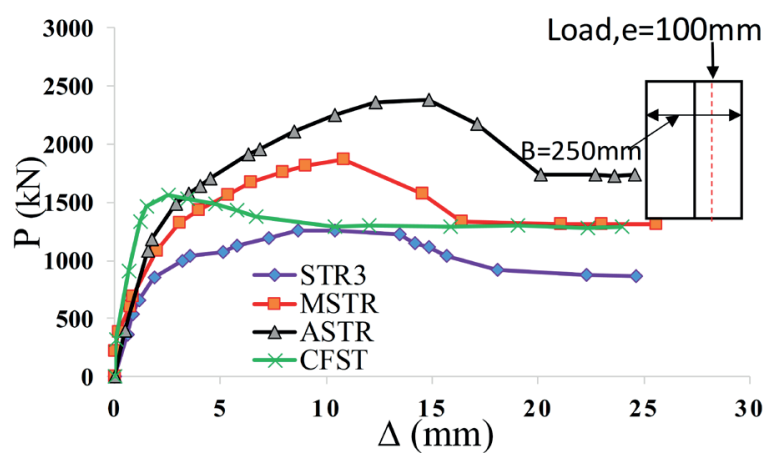

(d)

Fig. 9 Comparison of the P- $\Delta$ curve for columns under eccentric load at different distances

the CFST column. For instance, under the eccentricity of $\mathrm{e}=100 \mathrm{~mm}$, the bearing capacity of the STR 3 column was $19 \%$ smaller than that of the CFST column. As an interesting point, weight of the steel used in the CFST column is 3.48 times greater than STR3 column one.

According to the results presented in Fig. 9 and Table 8, the load capacity of the two columns MSTR and ASTR under pure compression load are 24 and 39 percent higher than that of the CFST column, respectively. Furthermore, under the eccentric load with eccentricity of $100 \mathrm{~mm}$, the load-bearing capacity of MSTR and ASTR columns were 18 and 53 percent higher than that of CFST column, respectively. At the same time, the ductility of these columns (MSTR and ASTR) under the load with an eccentricity of $100 \mathrm{~mm}$ is 11 and 30 percent higher than the ductility of the CFST column, respectively. As an interesting point, the weight of the steel consumed in ASTR column is 12 percent lower than the CFST column. Fig. 10(a) and Fig. 10(b) show the Von-Misses stress distributions in the spiral reinforcement of MTSRT column and steel tube of CFST column, respectively (for load with eccentricity of $100 \mathrm{~mm}$ ).

The energy absorption value (E) of the columns was calculated according to Fig. 11. According to Fig. 11, energy absorption value (E) defines as the area of the load-displacement curve up to the ultimate load $[64,65]$. Table 9 shows the energy absorption of each column (E) under the pure axial and eccentric loads.

Table 9 indicates that the energy absorption of the STR column, which is the strongest among the MTSTR columns, is 10.96 times higher than that of the CFST column under the axial loading. Also, the energy absorption of the STR column under the eccentric load with an eccentricity 


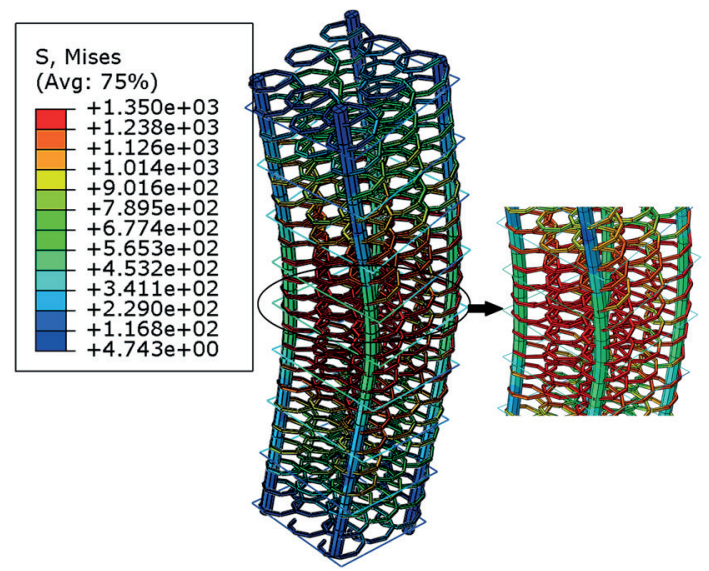

(a) von-Mises stresses-MTSTR

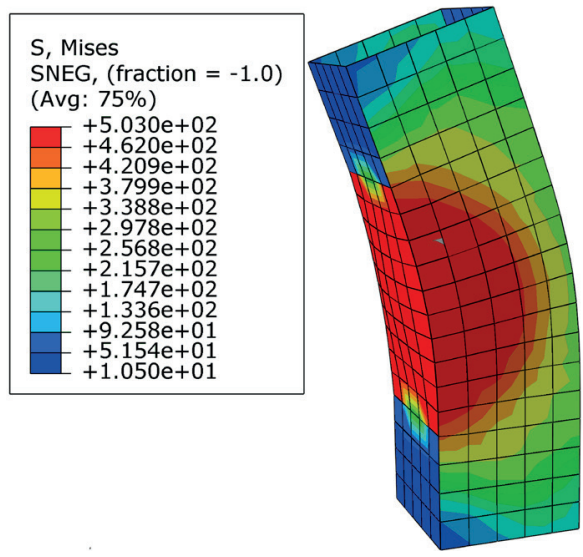

(b) von-Mises stresses-CFST

Fig. 10 Steel stresses developed within the CFST and STR columns

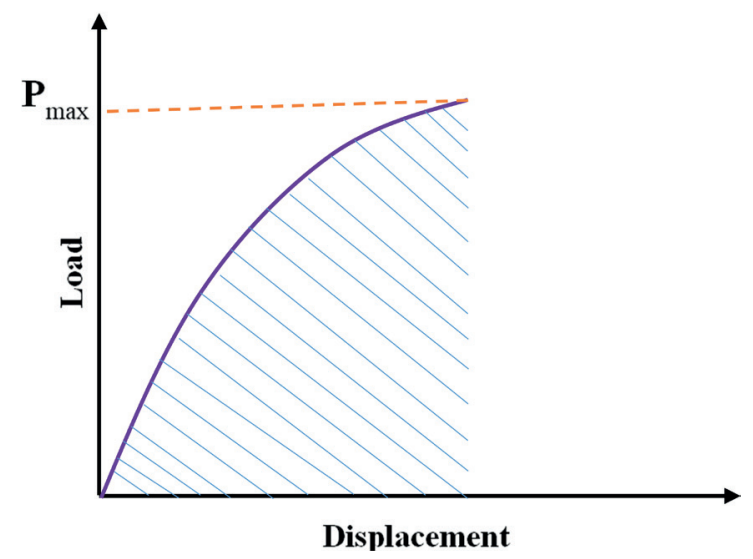

Fig. 11 Determination of energy absorption capacity

Table 9 Comparison of energy absorption of the columns

\begin{tabular}{lcccc}
\hline $\begin{array}{l}\text { Column } \\
\text { type }\end{array}$ & $\begin{array}{c}\mathrm{E}(\mathrm{kN} \times \mathrm{mm}) \\
\mathrm{e}=0 \mathrm{~mm}\end{array}$ & $\begin{array}{c}\mathrm{E}(\mathrm{kN} \times \mathrm{mm}) \\
\mathrm{e}=50 \mathrm{~mm}\end{array}$ & $\begin{array}{c}\mathrm{E}(\mathrm{kN} \times \mathrm{mm}) \\
\mathrm{e}=75 \mathrm{~mm}\end{array}$ & $\begin{array}{c}\mathrm{E}(\mathrm{kN} \times \mathrm{mm}) \\
\mathrm{e}=100 \mathrm{~mm}\end{array}$ \\
\hline STR3 & 6659 & 12281 & 11917 & 10615 \\
MSTR & 12360 & 16445 & 17777 & 15421 \\
ASTR & 36801 & 30540 & 26346 & 27161 \\
CFST & 3355 & 2246 & 3034 & 2788 \\
\hline
\end{tabular}

of $100 \mathrm{~mm}$ is 9.74 times greater than that of the CFST column with the same eccentricity. It should be noted that the weight of the steel used in the CFST column is 3.48 times greater than that of the STR3 column

\section{Conclusions}

This research focuses on the comparison between performances of two types of newly developed concrete columns under eccentric axial load using finite element method. This comparison was made between the bearing capacity, ductility and energy absorption of the MTSTR and CFST short columns. The results of this study showed that the load capacity, energy absorption and ductility of the MTSTR columns under the pure compression and eccentric compressive loads are more than those of the CFST column. The most important findings of this study are summarized as follows:

- The STR3 column is a type of the MTSTR columns contains eight circular spirals with a size of $4 \mathrm{~mm}$, a diameter of $70 \mathrm{~mm}$, a vertical spacing of $40 \mathrm{~mm}$ and finally, four corners placed longitudinal reinforcements with a diameter of $6 \mathrm{~mm}$. The STR 3 column shows a ductility of approximately two times higher than that of the CFST column under the axial compression. It is worth mentioning that the weight of the steel used in the CFST column is 3.48 times greater than that of the STR3 column (Fig. 9 and Table 8).

- Under the eccentric load, the STR3 column's bearing capacity is less than the CFST column. For instance, under the eccentricity of $\mathrm{e}=100 \mathrm{~mm}$, the bearing capacity of the STR3 column is $19 \%$ smaller than that of the CFST column (Fig. 9 and Table 8).

- The MSTR column is a type of the MTSTR columns contains 8 circular spirals with a size of $6 \mathrm{~mm}$, a diameter of $70 \mathrm{~mm}$, a vertical spacing of $40 \mathrm{~mm}$ and finally, four corners placed longitudinal reinforcements with a diameter of $6 \mathrm{~mm}$. The ASTR column is a type of the MTSTR columns contains 8 circular spirals with a size of $6 \mathrm{~mm}$, a diameter of $70 \mathrm{~mm}$, a vertical spacing of $40 \mathrm{~mm}$ and finally, 4 corners placed longitudinal reinforcements with a diameter of $20 \mathrm{~mm}$. The load capacity of the MSTR and ASTR columns under pure compression is 24 and 39 percent higher than that of the CFST column, respectively (Fig. 9 and Table 8).

- ASTR column was detected as the most robust column among the MTSTR columns (STR, MSTR, and ASTR) in the current study. 
- Under an eccentric load at a distance of $100 \mathrm{~mm}$ from the column center, the load-carrying capacity of the MSTR is 18 percent higher than that of the CFST column (Fig. 9 and Table 8).

- The bearing capacity of the ASTR column under the eccentric load with an eccentricity of $100 \mathrm{~mm}$ is $53 \%$ more than that of the CFST column, while the weight of the steel consumed in ASTR column is 12 percent lower than the CFST column (Fig. 9 and Table 8).

- The ductility of the ASTR column under the eccentric load with an eccentricity of $100 \mathrm{~mm}$ is 30

\section{References}

[1] Kim, H., Cho, S. "Column shortening of concrete cores and composite columns in a tall building", The Structural Design of Tall and Special Buildings,14(2), pp. 175-190, 2005. https://doi.org/10.1002/tal.269

[2] Kurc, O., Lulec, A. "A comparative study on different analysis approaches for estimating the axial loads on columns and structural walls at tall buildings", The Structural Design of Tall and Special Buildings, 22(6), pp. 485-499, 2013. https://oi.org/10.1002/tal.699

[3] Ying, M., Jin-xin, G. "Seismic Failure Modes and Deformation Capacity of Reinforced Concrete Columns under Cyclic Loads", Periodica Polytechnica Civil Engineering, 62(1), pp. 80-91, 2018. https://doi.org/10.3311/PPci.9893

[4] Mortezaei, A. "Plastic Hinge Length of RC Columns under the Combined Effect of Near-Fault Vertical and Horizontal Ground Motions", Periodica Polytechnica Civil Engineering, 58(3), pp. 243-253, 2014.

https://doi.org/10.3311/PPci.7329

[5] Ebadi Jamkhaneh, M., Kafi, M. A. "Experimental and Numerical Study of Octagonal Composite Column Subject to Various Loading", Periodica Polytechnica Civil Engineering, 62(2), pp. 413-422, 2018. https://doi.org/10.3311/PPci.11334

[6] Jalilzadeh Afshari, M., Kheyroddin, A., Gholhaki, M. "Simplified Time-Dependent Column Shortening Analysis in Special Reinforced Concrete Moment Frames", Periodica Polytechnica Civil Engineering, 62(1), pp. 232-249, 2018.

https://doi.org/10.3311/PPci.10679

[7] Shoeibi, S., Kafi, M. A., Gholhaki, M. "Performance-Based Seismic Design and Parametric Assessment of Linked Column Frame System", Periodica Polytechnica Civil Engineering, 62(3), pp. 555569,2018

https://doi.org/10.3311/PPci.10920

[8] Bai, Z. Z., Au, F. T. K. "Flexural ductility design of high-strength concrete columns", The Structural Design of Tall and Special Buildings, 22(1), pp. 92-115, 2013.

https://doi.org/10.1002/tal.662

[9] Kurčik, F., Bouchaïr, A., Vičan, J. "A probabilistic approach for a T-stub ultimate strength assessment using response-surface approximation", Periodica Polytechnica Civil Engineering, 52(1), pp. 15-22, 2008. https://doi.org/10.3311/pp.ci.2008-1.02 percent higher than that of the CFST column (Fig. 9 and Table 8).

- The energy absorption capacity of the ASTR column under the eccentric load with an eccentricity of $100 \mathrm{~mm}$ is 9.74 times greater than that of the CFST column (Table 9).

\section{Acknowledgement}

The authors wish to express their gratitude to the research council of Shahid Chamran University of Ahvaz for their financial supports.

[10] Akhaveissy, A. H., Permanoon, A., Mirzaei, M. "Seismic Retrofit of Defective RC Beam-Column Joints", Periodica Polytechnica Civil Engineering, 62(3), pp. 596-611, 2018. https://doi.org/10.3311/PPci.10661

[11] Kim, H. S., Jeong, S. H., Shin, S. H. "Column shortening analysis of tall buildings with lumped construction sequences", The Structural Design of Tall and Special Buildings, 21(10), pp. 764-776, 2012. https://doi.org/10.1002/tal.650

[12] Qian, K., Li, B. "Dynamic and residual behavior of reinforced concrete floors following instantaneous removal of a column", Engineering Structures, 148, pp. 175-184, 2017. https://doi.org/10.1016/j.engstruct.2017.06.059

[13] Qian, K., Weng, Y. H., Li, B. "Impact of two columns missing on dynamic response of RC flat slab structures", Engineering Structures, 177, pp. 598-615, 2018. https://doi.org/10.1016/j.engstruct.2018.10.011

[14] Xu, M., Gao, S., Zhang, S., Li, H. "Experimental study on bolted CFST-column joints with different configurations in accommodating column-loss", Journal of Constructional Steel Research, 151, pp. 122-131, 2018. https://doi.org/10.1016/j.jcsr.2018.09.021

[15] Avraam, T. P., Fasoulakis, Z. C. "Nonlinear postbuckling analysis of frames with varying cross-section columns", Engineering Structures, 56, pp. 1-7, 2013. https://doi.org/10.1016/j.engstruct.2013.04.010

[16] Huang, L., Gao, C., Yan, L., Yu, T., Kasal, B. "Experimental and numerical studies of CFRP tube and steel spiral dual-confined concrete composite columns under axial impact loading", Composites Part B: Engineering, 152, pp. 193-208, 2018. https://doi.org/10.1016/j.compositesb.2018.07.008

[17] Huang, L., Sun, X., Yan, L., Kasal, B. "Impact behavior of concrete columns confined by both GFRP tube and steel spiral reinforcement", Construction and Building Materials, 131, pp. 438-448, 2017. https://doi.org/10.1016/j.conbuildmat.2016.11.095

[18] Huang, L., Lu, Y. Q., Xu, Z. P. "Correctional recommendation of bearing capacity formula of RC eccentric compression members", Engineering Mechanics, 29(6), pp. 169-175, 2012. [online] Available at: http://engineeringmechanics.cn/EN/10.6052/j. issn.1000-4750.2010.07.0503 [Accessed: 10 October 2019] 
[19] Yin, P., Huang, L., Yan, L., Zhu, D. "Compressive behavior of concrete confined by CFRP and transverse spiral reinforcement. Part A: experimental study", Materials and Structures, 49(3), pp. 1001$1011,2016$. https://doi.org/10.1617/s11527-015-0554-1

[20] Yu, B., Liu, S., Li, B. "Probabilistic Calibration for Shear Strength Models of Reinforced Concrete Columns", Journal of Structural Engineering, 145(5), Article number: 04019026-1-14, 2019. https://doi.org/10.1061/(ASCE)ST.1943-541X.0002307

[21] Vu, N. S., Yu, B., Li, B. "Prediction of strength and drift capacity of corroded reinforced concrete columns", Construction and Building Materials, 115, pp. 304-318, 2016.

https://doi.org/10.1016/j.conbuildmat.2016.04.048

[22] Vu, N., Li, B. "Seismic Performance Assessment of Corroded Reinforced Concrete Short Columns", Journal of Structural Engineering, 144(4), Article number: 04018018-1, 2018. https://doi.org/10.1061/(ASCE)ST.1943-541X.0001994

[23] Pan, Y., Cao, S. Y., Jing, D. H., Zhao, S. C. "Experimental Research on Axially Loaded Circular Concrete Columns Confined by CFRP under Preload", Advanced Materials Research, 255-260, pp. 694698, 2011.

https://doi.org/10.4028/www.scientific.net/AMR.255-260.694

[24] Yang, Y. F., Han, L. H. "Concrete filled steel tube (CFST) columns subjected to concentrically partial compression", Thin-Walled Structures, 50(1), pp. 147-156, 2012.

https://doi.org/10.1016/j.tws.2011.09.007

[25] Evirgen, B., Tuncan, A., Taskin, K. "Structural behavior of concrete filled steel tubular sections (CFT/CFSt) under axial compression", Thin-Walled Structures, 80, pp. 46-56, 2014.

https://doi.org/10.1016/j.tws.2014.02.022

[26] Shen, Q., Wang, J., Wang, J., Ding, Z. "Axial compressive performance of circular CFST columns partially wrapped by carbon FRP", Journal of Constructional Steel Research, 155, pp. 90-106, 2019. https://doi.org/10.1016/j.jcsr.2018.12.017

[27] Li, B., Wang, J., Lu, Y., Zhang, Z., Wang, J. "Seismic response tests and analytical assessment of blind bolted assembly CFST frames with beam-connected SPSWs", Engineering Structures, 178, pp. 343-360, 2019.

https://doi.org/10.1016/j.engstruct.2018.10.009

[28] Wang, J., Lu, J., Zhang, H., Zhao, C. "Experimental investigation on seismic performance of endplate composite joints to CFST columns", Journal of Constructional Steel Research, 145, pp. 352-367, 2018.

https://doi.org/10.1016/j.jcsr.2018.03.006

[29] Wang, J., Wang, F., Shen, Q. "Numerical modelling and design recommendation of axially-loaded thin-walled RCFST slender column", Thin-Walled Structures, 135, pp. 210-226, 2019.

https://doi.org/10.1016/j.tws.2018.11.004

[30] Wang, J., Zhang, N. "Performance of circular CFST column to steel beam joints with blind bolts", Journal of Constructional Steel Research, 130, pp. 36-52, 2017. https://doi.org/10.1016/j.jcsr.2016.11.026

[31] Lam, D., Williams, C. A. "Experimental study on concrete filled square hollow sections", Steel and Composite Structures, 4(2), pp. 95-112, 2004.

https://doi.org/10.12989/scs.2004.4.2.095
[32] Sakino, K., Nakahara, H., Morino, S., Nishiyama, I. "Behavior of Centrally Loaded Concrete-Filled Steel-Tube Short Columns", Journal of Structural Engineering, 130(2), Article number: 180, 2004.

https://doi.org/10.1061/(ASCE)0733-9445(2004)130:2(180)

[33] Qiao, Q., Li, X., Cao, W., Dong, H. "Seismic behavior of specially shaped concrete-filled steel tube columns with multiple cavities", The Structural Design of Tall and Special Buildings, 27(12), Article number: e1485, 2018. https://doi.org/10.1002/tal.1485

[34] Xiong, M. X., Xiong, D. X., Liew, J. Y. R. "Behaviour of steel tubular members infilled with ultra high strength concrete", Journal of Constructional Steel Research, 138, pp. 168-183, 2017. https://doi.org/10.1016/j.jcsr.2017.07.001

[35] Lee, H. J., Choi, I. R., Park, H. G. "Eccentric Compression Strength of Rectangular Concrete-Filled Tubular Columns Using HighStrength Steel Thin Plates", Journal of Structural Engineering, 143(5), Article number: 04016228, 2016. https://doi.org/10.1061/(ASCE)ST.1943-541X.0001724

[36] Wang, J., Shen, Q., Wang, F., Wang, W. "Experimental and analytical studies on CFRP strengthened circular thin-walled CFST stub columns under eccentric compression", Thin-Walled Structures, 127, pp. 102-119, 2018.

https://doi.org/10.1016/j.tws.2018.01.039

[37] Li, G., Chen, B., Yang, Z., Feng, Y. "Experimental and numerical behaviour of eccentrically loaded high strength concrete filled high strength square steel tube stub columns", Thin-Walled Structures, 127, pp. 483-499, 2018.

https://doi.org/10.1016/j.tws.2018.02.024

[38] Liu, X., Xu, C., Liu, J., Yang, Y. "Research on special-shaped concrete-filled steel tubular columns under axial compression", Journal of Constructional Steel Research, 147, pp. 203-223, 2018. https://doi.org/10.1016/j.jcsr.2018.04.014

[39] Tran, C. T. N., Li, B. "Seismic performance of RC short columns with light transverse reinforcement", Structural Engineering and Mechanics, 67(1), pp. 93-104, 2018. https://doi.org/10.12989/sem.2018.67.1.093

[40] Tran, C. T. N., Li, B. "Experimental Studies on the Backbone Curves of Reinforced Concrete Columns with Light Transverse Reinforcement", Journal of Performance of Constructed Facilities, 29(5), Article number: 04014126, 2015.

https://doi.org/10.1061/(ASCE)CF.1943-5509.0000626

[41] Tran, C. T. N., Li, B. "Ultimate Displacement of Reinforced Concrete Columns with Light Transverse Reinforcement", Journal of Earthquake Engineering, 17(2), pp. 282-300, 2013. https://doi.org/10.1080/13632469.2012.730117

[42] Tran, C. T. N., Li, B. "Shear Strength Model for Reinforced Concrete Columns with Low Transverse Reinforcement Ratios", Journal of Advances in Structural Engineering, 17(10), pp. 1373-1386, 2014. https://doi.org/10.1260/1369-4332.17.10.1373

[43] Jing, D. H., Yu, T., Liu, X. D. "New configuration of transverse reinforcement for improved seismic resistance of rectangular RC columns: Concept and axial compressive behavior", Engineering Structures, 111, pp. 383-393, 2016. https://doi.org/10.1016/j.engstruct.2015.12.014 
[44] Li, Y., Cao, S., Jing, D. H. "Axial compressive behaviour of RC columns with high-strength MTS transverse reinforcement", Magazine of Concrete Research, 69(9), pp. 436-452, 2017. https://doi.org/10.1680/jmacr.16.00328

[45] Li, Y., Cao, S., Jing, D. H. "Analytical compressive stress-strain model for concrete confined with high-strength multiple-tied-spiral transverse reinforcement", The Structural Design of Tall and Special Buildings, 27(2), Article number: e1416, 2018. https://doi.org/10.1002/tal.1416

[46] Han, L. H., Yao, G. H., Tao, Z. "Performance of concrete-filled thin-walled steel tubes under pure torsion", Thin-Walled Structures, 45(1), pp. 24-36, 2007. https://doi.org/10.1016/j.tws.2007.01.008

[47] Han, L. H., Li, W., Bjorhovde, R. "Developments and advanced applications of concrete-filled steel tubular (CFST) structures: Members", Journal of Constructional Steel Research, 100, pp. 211228, 2014.

https://doi.org/10.1016/j.jcsr.2014.04.016

[48] Han, L. H. "Flexural behavior of concrete-filled steel tubes", Journal of Constructional Steel Research, 60(2), pp. 313-337, 2004. https://doi.org/10.1016/j.jcsr.2003.08.009

[49] Labibzadeh, M., Hamidi, R. "A Comparison Between Shear Capacities of Two Composite Shear Walls: DSCSWs and CSPSWs", Structural Engineering International, 29(2), pp. 276-281, 2019. https://doi.org/10.1080/10168664.2018.1544473

[50] Labibzadeh, M., Firouzi, A., Ghafouri, H. R. "Structural performance evaluation of an aged structure using a modified plasticity model in inverse solution method", Inverse Problems in Science and Engineering, 26(9), pp. 1326-1355, 2018. https://doi.org/10.1080/17415977.2017.1400028

[51] Labibzadeh, M., Elahifar, T. "An Enhanced Finite Element Model for Reinforced Concrete Two-Way Slabs Strengthened with Carbon Fiber Reinforced Polymers", Structural Engineering International, 25(1), pp. 81-90, 2015. https://doi.org/10.2749/101686614X14043795570093

[52] Behnam, H., Kuang, J. S., Samali, B. "Parametric finite element analysis of RC wide beam-column connections", Computers and Structures, 205, pp. 28-44, 2018.

https://doi.org/10.1016/j.compstruc.2018.04.004

[53] Behnam, H., Kuang, J. S., Huang, R. Y. C. "Exterior RC wide beam-column connections: Effect of beam width ratio on seismic behaviour", Engineering Structures, 147, pp. 27-44, 2017. https://doi.org/10.1016/j.engstruct.2017.05.044

[54] Behnam, H., Kuang, J. S., Abdouka, K. "Effect of post-tensioned spandrel beam on wide beam-column connections", Magazine of Concrete Research, 70(1), pp. 28-41, 2018. https://doi.org/10.1680/jmacr.17.00071
[55] Hossain, K. M. A., Wright, H. D. "Design Aspect of Double Skin Profiled Composite Framed Shearwalls in Construction and Service Stages", ACI Structural Journal, 101(1), pp. 94-102, 2004. https://doi.org/10.14359/13002

[56] Rafiei, S., Hossain, K. M. A., Lachemi, M., Behdinan, K., Anwar, M. S. "Finite element modeling of double skin profiled composite shear wall system under in-plane loadings", Engineering Structures, 56, pp. 46-57, 2013.

https://doi.org/10.1016/j.engstruct.2013.04.014

[57] Hossain, K. M. A., Rafiei, S., Lachemi, M., Behdinan, K. "Structural performance of profiled composite wall under in-plane cyclic loading", Engineering Structures, 110, pp. 88-104, 2016.

https://doi.org/10.1016/j.engstruct.2015.11.057

[58] Rezaifar, O., Hasanzadeh, M., Gholhaki, M. "Concrete made with hybrid blends of crumb rubber and metakaolin: Optimization using Response Surface Method", Construction and Building Materials, 123, pp. 59-68, 2016. https://doi.org/10.1016/j.conbuildmat.2016.06.047

[59] Gholhaki, M., Kheyroddin, A., Hajforoush, M., Kazemi, M. "An investigation on the fresh and hardened properties of self-compacting concrete incorporating magnetic water with various pozzolanic materials", Construction and Building Materials, 158, pp. 173-180, 2018. https://doi.org/10.1016/j.conbuildmat.2017.09.135

[60] Hariri-Ardebili, M. A., Saouma, V. E. "Sensitivity and uncertainty quantification of the cohesive crack model", Engineering Fracture Mechanics, 155, pp. 18-35, 2016.

https://doi.org/10.1016/j.engfracmech.2016.01.008

[61] Hariri-Ardebili, M. A., Saouma, V. E. "Probabilistic seismic demand model and optimal intensity measure for concrete dams", Structural Safety, 59, pp. 67-85, 2016.

https://doi.org/10.1016/j.strusafe.2015.12.001

[62] Yun, X., Gardner, L. "Stress-strain curves for hot-rolled steels", Journal of Constructional Steel Research, 133, pp. 36-46, 2017. https://doi.org/10.1016/j.jcsr.2017.01.024

[63] Yun, X., Gardner, L. "Numerical modelling and design of hot-rolled and cold-formed steel continuous beams with tubular cross-sections", Thin-Walled Structures, 132, pp. 574-584, 2018. https://doi.org/10.1016/j.tws.2018.08.012

[64] Abdulraheem, M. S., Kadhum, M. M. "Experimental investigation of fire effects on ductility and stiffness of reinforced reactive powder concrete columns under axial compression", Journal of Building Engineering, 20, pp. 750-761, 2018. https://doi.org/10.1016/j.jobe.2018.07.028

[65] Yu, R., Spiesz, P., Brouwers, H. J. H. "Energy absorption capacity of a sustainable Ultra-High Performance Fibre Reinforced Concrete (UHPFRC) in quasi-static mode and under high velocity projectile impact", Cement and Concrete Composites, 68, pp. 109-122, 2016. https://doi.org/10.1016/j.cemconcomp.2016.02.012 